\title{
Polydactyly: a study of a five generation Indian family
}

Uppala Radhakrishna, Asha S Multani, Jitendra V Solanki, Vinod C Shah, Niloufer J Chinoy

\section{Abstract}

Preaxial polydactyly was observed in up to five generations of an Indian family living in a village in the Rajkot district (Gujarat). Among the 71 affected members, 45 were males and 26 were females. All these affected members showed preaxial polydactyly manifesting as a well formed, articulated extra digit of the hand or foot. Twenty other cases were also identified with polydactyly involving triphalangeal digits replacing the thumbs or duplication of the big toe(s). To the best of our knowledge, the present family is the largest in which several members have preaxial polydactyly of different types. No other abnormalities were apparent. The present study strongly suggests that preaxial polydactyly with a well formed extra digit,
Biotechnology, National Dairy Development Board, Anand 388 001, India. U Radhakrishna

Department of Zoology, School of Sciences, Gujarat University,

Ahmedabad 380009 , India.

A S Multani

N J Chinoy

Department of Animal Genetics and Breeding, Veterinary College, Anand 388 001 , India. J V Solank

MS University,

Baroda 390 002, India. V C Shah

Correspondence to Dr Radhakrishna.

Received 29 April 1992. Revised version accepted 2 September 1992

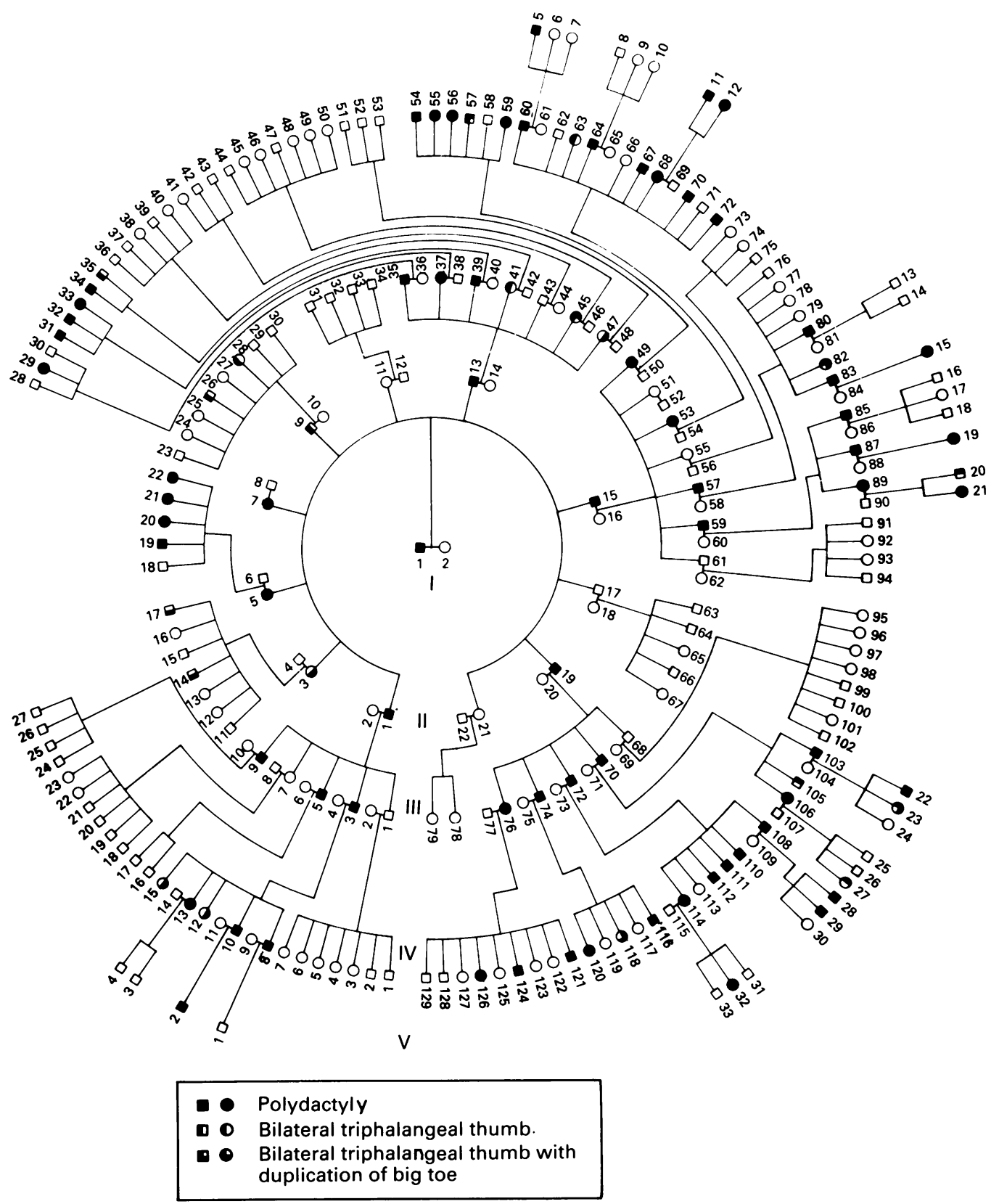

Figure 1 Pedigree of the family. 
triphalangeal thumbs, and duplication of the big toe can be manifestations of the

Table 1 Details of affected subjects.

\begin{tabular}{|c|c|c|c|c|c|c|c|}
\hline No & Pedigree No & RH & LH & RF & LF & Remarks & I reports on the largest \\
\hline 1 & I·1 & 6 & 6 & 5 & 5 & & digit a trinhal \\
\hline 2 & II $\cdot 1$ & 6 & 6 & 5 & 5 & & sisting or a well \\
\hline 3 & II. 3 & 5 & 5 & 5 & 5 & TT & geal digit in place of the thumb, duplication of \\
\hline 4 & II $\cdot 5$ & 6 & 6 & 5 & $\begin{array}{l}5 \\
5\end{array}$ & & the big toe, or hexadactyly, representing a high \\
\hline $\begin{array}{l}5 \\
6\end{array}$ & $\begin{array}{l}\text { II } \cdot 7 \\
\text { II } 9\end{array}$ & $\begin{array}{l}6 \\
5\end{array}$ & $\begin{array}{l}6 \\
5\end{array}$ & $\begin{array}{l}5 \\
5\end{array}$ & $\begin{array}{l}5 \\
5\end{array}$ & TT & degree of genetic variability. All affected sub \\
\hline 7 & II $\cdot 13$ & 6 & 6 & 5 & 5 & & 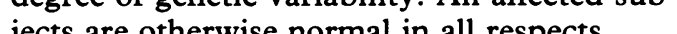 \\
\hline 8 & $\mathrm{II} \cdot 15$ & 6 & 6 & 5 & 5 & & \\
\hline 9 & II $\cdot 19$ & 6 & 6 & 6 & 6 & & \\
\hline 10 & III $\cdot 3$ & 6 & 6 & 5 & 5 & & \\
\hline 11 & III $\cdot 5$ & 6 & 6 & 5 & 5 & & \\
\hline 12 & III $\cdot 9$ & 6 & 6 & 5 & 5 & & Family report \\
\hline 13 & III $\cdot 14$ & 5 & 5 & 5 & 5 & TT & The family studied were inhahitant \\
\hline 14 & III 17 & 5 & 5 & 5 & 5 & TT & . \\
\hline 15 & III 19 & 6 & 6 & 5 & 5 & & lage in the Rajkot district of Gujarat \\
\hline 16 & III. 20 & 6 & 6 & 5 & 5 & & 265 subjects in five generations of the pedigree \\
\hline $\begin{array}{l}17 \\
18\end{array}$ & III $\cdot 21$ & 6 & 6 & 6 & 6 & & (fig 1 ) there were 45 affected males and 26 \\
\hline $\begin{array}{l}18 \\
19\end{array}$ & $\begin{array}{l}\text { III.22 } \\
\text { UI. } 26\end{array}$ & $\begin{array}{l}6 \\
5\end{array}$ & 6 & 5 & $\begin{array}{l}5 \\
5\end{array}$ & TT & (ng 1), there were 45 antected males and 20 \\
\hline 20 & $\begin{array}{l}111 \cdot 20 \\
\text { III } \cdot 28\end{array}$ & $\begin{array}{l}3 \\
5\end{array}$ & $\begin{array}{l}3 \\
5\end{array}$ & $\begin{array}{l}3 \\
5\end{array}$ & $\begin{array}{l}5 \\
5\end{array}$ & TT & affected females who had polydactyly w \\
\hline 21 & III. 35 & 6 & 6 & 5 & 5 & & variable expression (table 1 ). Figs 2 to 8 show \\
\hline 22 & III $\cdot 37$ & 6 & 5 & 5 & 5 & & \\
\hline 23 & III $\cdot 39$ & 6 & 6 & 5 & 5 & & \\
\hline 24 & III $\cdot 41$ & 5 & 5 & 5 & 5 & TT & \\
\hline 25 & III 45 & 5 & 5 & 5 & 5 & TT \& DB & \\
\hline 26 & III $\cdot 47$ & 5 & 5 & 5 & 5 & TT & \\
\hline 27 & $\begin{array}{l}\text { III } \cdot 49 \\
\text { III.53 }\end{array}$ & 6 & 6 & 5 & 5 & & \\
\hline 29 & III. 57 & $\begin{array}{l}0 \\
6\end{array}$ & 5 & 5 & 5 & TT & \\
\hline 30 & III 59 & 6 & 6 & 5 & 5 & & \\
\hline 31 & III $\cdot 70$ & 6 & 6 & 6 & 6 & & \\
\hline 32 & III $\cdot 72$ & 6 & 6 & 6 & 6 & & \\
\hline 33 & III.74 & 6 & 6 & 5 & 5 & & \\
\hline 34 & III. 76 & 6 & 6 & 5 & 5 & & \\
\hline 35 & IV 8 & 6 & 6 & 5 & 5 & & \\
\hline 36 & IV 10 & 6 & 7 & 5 & 5 & & \\
\hline 37 & IV $\cdot 12$ & 5 & 5 & 5 & 5 & TT & \\
\hline 38 & IV 13 & 6 & 6 & 5 & 5 & & \\
\hline 39 & IV. 15 & 5 & 5 & 5 & 5 & TT & \\
\hline 40 & IV 29 & 6 & 6 & 5 & 5 & & \\
\hline 41 & IV. 31 & 6 & 6 & 5 & 5 & & \\
\hline 42 & IV.32 & 6 & 6 & 5 & 5 & & \\
\hline 43 & IV. 33 & 6 & 6 & 5 & 5 & & \\
\hline 44 & IV 35 & 5 & 5 & 5 & 5 & TT & \\
\hline 45 & IV 54 & 6 & 6 & 5 & 5 & & Figure 2 III.39: bilateral fully developed extra finger \\
\hline 46 & IV. 55 & 6 & 6 & 5 & 5 & & on both hands. \\
\hline 47 & IV. 56 & 6 & 6 & 5 & 5 & & \\
\hline 48 & IV. 57 & 5 & 5 & 5 & 5 & TT \& DB & \\
\hline 49 & IV.59 & 6 & 6 & 5 & 5 & & \\
\hline 50 & IV 60 & 6 & 6 & 5 & 5 & & \\
\hline 51 & IV.63 & 5 & 5 & 5 & 5 & TT & \\
\hline 52 & IV. 64 & 6 & 6 & 6 & 5 & & \\
\hline 53 & IV. 67 & 6 & 6 & 5 & 5 & & \\
\hline 54 & IV 68 & 6 & 6 & 5 & 5 & & \\
\hline 55 & IV $\cdot 70$ & 6 & 6 & 5 & 5 & & \\
\hline 56 & IV 71 & 6 & 6 & 5 & 5 & & \\
\hline 57 & IV 72 & 6 & 6 & 5 & 5 & & \\
\hline 58 & IV 80 & 6 & 6 & 5 & 5 & & \\
\hline 59 & IV. 82 & 5 & 5 & 5 & 5 & TT \& DB & \\
\hline $\begin{array}{l}60 \\
61\end{array}$ & $\begin{array}{l}\text { IV } 83 \\
\text { IV. } 85\end{array}$ & $\begin{array}{l}6 \\
6\end{array}$ & $\begin{array}{l}7 \\
6\end{array}$ & $\begin{array}{l}6 \\
5\end{array}$ & $\begin{array}{l}6 \\
5\end{array}$ & & \\
\hline 62 & IV 87 & 6 & 6 & 5 & 5 & & \\
\hline 63 & IV 89 & 6 & 5 & 5 & 5 & & \\
\hline 64 & IV $\cdot 103$ & 6 & 6 & 5 & 5 & & \\
\hline 65 & IV 105 & 5 & 5 & 5 & 5 & TT & \\
\hline 66 & IV 106 & 6 & 6 & 5 & 5 & & \\
\hline 67 & IV $\cdot 108$ & 6 & 6 & 5 & 5 & & \\
\hline
\end{tabular}

Figure 3 III.57: six fingers on the left hand and five fingers with triphalangeal thumb on the right hand.

TT \& DB

IV $\cdot 116$

IV $\cdot 118$

IV $\cdot 120$

IV. 124

IV. 126

V.2
V.5

V.11

$V \cdot 12$
$V \cdot 15$

V.19

V.20

$V \cdot 21$
$V \cdot 22$

V.23

V.27

V.29

$\mathrm{V} \cdot 30$
$\mathrm{~V} \cdot 32$

same autosomal dominant gene. It is likely that other factors are modifying the expression of this gene.

(f Med Genet 1993;30:296-9)

This paper reports on the largest known Indian family with preaxial polydactyly congeal digit in place of the thumb, duplication of the big toe, or hexadactyly, representing a high degree of genetic variability. All affected sub-

Family report

lage in the Rajkot district of Gujarat. Among affected females who had polydactyly with variable expression (table 1). Figs 2 to 8 show

$H=$ right hand, $L H=$ left hand, $R F=$ right foot, $L F=$ left foot, $T T=$ bilateral triphalangeal thumbs, $\mathrm{DB}=$ unilateral duplication of big toe (either side). 


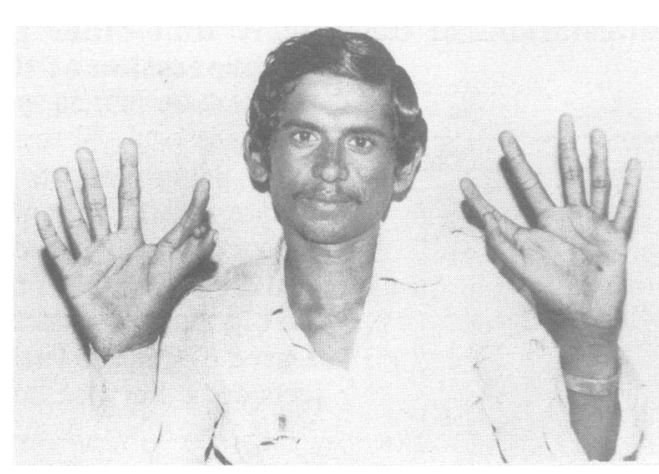

Figure 5 IV.83: bilateral polydactyly with seven fingers on the right hand and six fingers on the left hand.

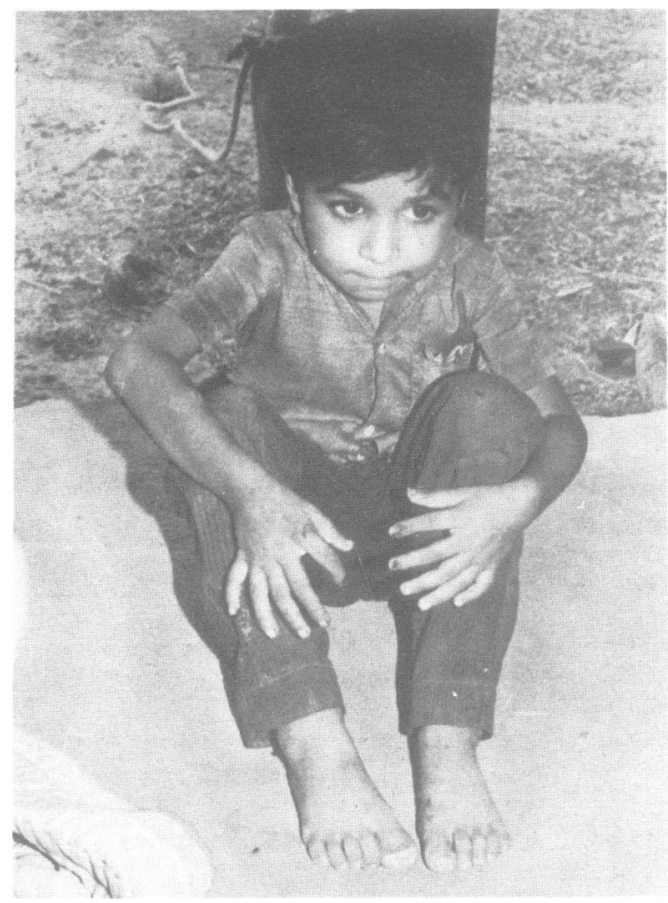

Figure $6 \quad V \cdot 5$ : six fingers on both hands with unilateral duplication of the big toe.

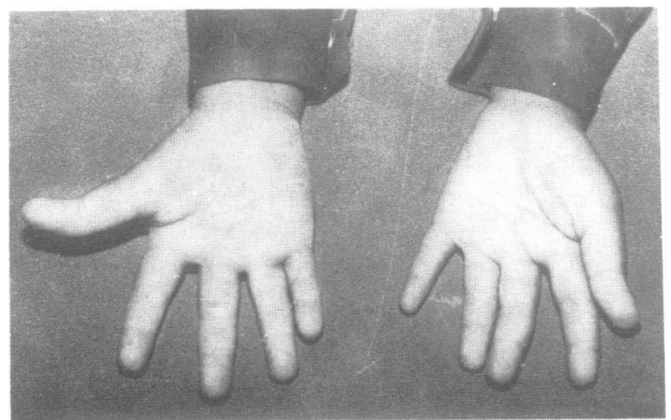

Figure $7 \quad V \cdot 20$ : bilateral triphalangeal thumbs.

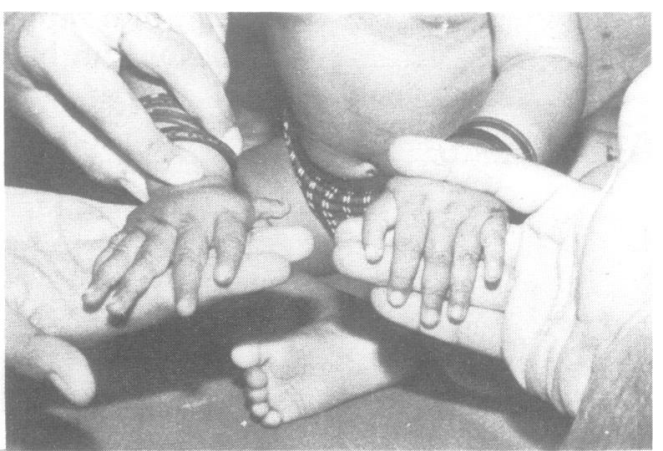

Figure $8 \quad V \cdot 21$ : polydactyly with six fingers on the right hand and triphalangeal thumb on the left hand.

the various types of polydactyly in different subjects. Of the 71 members with polydactyly, five were symmetrically affected in both hands and feet, whereas 56 subjects had six digits bilaterally on their hands only. The rest of the affected subjects $(n=10)$ showed asymmetry in the number of digits in their hands or feet or both. In addition to those with a well developed extra digit, 20 other subjects had bilateral triphalangeal thumbs or unilateral duplication of the big toes or both, indicating a high degree of phenotypic variation.

Marriages between affected and normal subjects produced affected and normal progeny in a 1:1 ratio. This clearly suggests that the polydactyly is caused by an autosomal dominant gene (table 2). Further, distribution of polydactyly in the two sexes clearly indicates that the expression of the trait is in no way influenced by or linked to the sex of the subject (table 3). Male to male transmission was observed in several instances.

The majority of the family members were agricultural labourers but this anomaly does not interfere with their work. According to the information available and our observations, there were no other malformations, parental consanguinity, or reduction in reproductive fitness in the family.

The present data support autosomal dominant inheritance with variable expression.

\section{Discussion}

The incidence of polydactyly in the general population shows quite wide variation among various racial groups ranging from 0.37 to 1.2 in 1000 live births. ${ }^{1-4}$ The incidence in embryos studied through induced abortions in Japan was found to be $0.35 \% .^{5}$ Similar information is not available for the Indian population.

Published reports have suggested that preaxial polydactyly involving duplication of the thumbs/big toes, triphalangeal thumbs/ duplication of the big toes, and polydactyly of an index finger are three different types of autosomal dominant preaxial polydactyly. However, all three phenotypes are present in the family reported here. In the family under study, parents with a triphalangeal thumb (fig 7) and duplication of a big toe did not produce offspring with a fully developed extra finger or toe. They produced the same type or normal offspring. However, the parents with preaxial 
Table 2 Distribution of preaxial polydactyly in offspring from marriages in four generations.

\begin{tabular}{|c|c|c|c|c|c|}
\hline \multirow[b]{2}{*}{ Generation } & \multirow[b]{2}{*}{ Parents } & \multirow{2}{*}{$\begin{array}{c}\text { No of } \\
\text { marriages }\end{array}$} & \multicolumn{2}{|c|}{ Offspring } & \multirow{2}{*}{$\begin{array}{l}\text { Calculated } \\
\chi^{2} \text { value }\end{array}$} \\
\hline & & & Affected & Normal & \\
\hline I & Affected $\times$ normal & 1 & $\begin{array}{c}8 \\
(6 \cdot 5)\end{array}$ & $\begin{array}{c}5 \\
(6 \cdot 5)\end{array}$ & 0.6923 \\
\hline II & Affected $\times$ normal & 8 & $\begin{array}{c}25 \\
(25 \cdot 5)\end{array}$ & $\begin{array}{c}26 \\
(25 \cdot 5)\end{array}$ & 0.0196 \\
\hline III & Affected $\times$ normal & 16 & $\begin{array}{c}43 \\
(42 \cdot 0)\end{array}$ & $\begin{array}{c}41 \\
(42 \cdot 0)\end{array}$ & 0.0476 \\
\hline IV & Affected $\times$ normal & 15 & $\begin{array}{c}14 \\
(18 \cdot 0)\end{array}$ & $\begin{array}{c}22 \\
(18 \cdot 0)\end{array}$ & 0.4444 \\
\hline
\end{tabular}

Figures in parentheses indicate expected numbers in each group.

All calculated $\chi^{2}$ values were statistically non-significant $(\mathrm{p}<0.05)$

Table 3 Distribution of preaxial polydactyly in the two sexes.

\begin{tabular}{lccc}
\hline & \multicolumn{2}{c}{ Sex } & Calculated \\
\cline { 2 - 3 } Generations & Male & Female & $\chi^{2}$ value \\
\hline II & 5 & 3 & 0.50 \\
III & 14 & 11 & 0.36 \\
IV & 27 & 16 & 2.8139 \\
V & 7 & 7 & 0.0000 \\
\hline
\end{tabular}

All calculated $\chi^{2}$ values are statistically non-significant $(p<0.05)$.

polydactyly with fully developed triphalangeal digits in addition to the thumb produced children with a similar type and/or triphalangeal thumb and duplication of the big toe polydactyly, perhaps suggesting a degree of genetic anticipation.

Graham $e t$ al reported absence of the thenar intrinsic muscles in four unrelated families with preaxial thumb polydactyly, which was associated with inability to flex the thumb across the palm. However, such observations were not made in the present family, since the extra digit was functional and flexed like a normal finger.

Occurrence of preaxial polydactyly of a well formed extra digit, triphalangeal thumbs, and duplication of the big toe in the same pedigree indicates a common genetic basis responsible for all the varieties. The asymmetry or variation in expression may be the result of involvement of modifying genes, polygenes, or some unrecognised effect on the developmental process. The data presented in table 2 clearly indicate that the mode of inheritance of polydactyly in the present study is autosomal dominant.

The distribution of polydactyly in the two sexes is presented in table 3 . These findings indicate an even distribution of polydactyly in both sexes. The number of affected males was found to be higher than affected females in different generations, but on statistical analysis this was found to be non-significant. Furthermore, the pedigree clearly indicates that there is equal transmission of the trait to both sexes from affected male or female parents. This suggests that the expression of polydactyly is independent of sex. Temtamy ${ }^{6}$ also reported equal expression of this trait in the two sexes.

The University Grants Commission, Government of India, New Delhi is gratefully acknowledged for providing financial support under the DSA programme. Thanks are due to Dr B K Patel, Government Veterinary Officer in the area, for help in collecting the necessary information.

1 Castilla E, Paz J, Mutchinick O, Munoz E, Giargivtti E, Gelman Z. Polydactyly: a genetic study in South America. Gelman Z. Polydactyly: a genetic study in South America. Am f Hum Genet 1973;25:405-12.

oolf CM, Woolf RM. A genetic study of polydactyly in Utah. Am f Hum Genet 1970;22:75-8.

3 Ohkura K. Clinical genetics of polydactylism. fpn $f \mathrm{Hum}$ Genet 1956;1:11-23.

4 Neel JV. A study of major congenital defects in Japanese infants. Am $\mathcal{F}$ Hum Genet 1958;10:398-445.

5 Shiota K, Matsunaga E. A genetic and epidemiologic study of polydactyly in human embryos in Japan. $f_{p n} \mathcal{f} \mathrm{Hum}$ Genet 1978;23:173-92.

6 Temtamy SA. Polydactyly. In: Bergsma D, ed. Birth defects compendium. 2nd ed. New York, MacMillan, 1979:814.

7 Graham JM, Brown FE, Hall BD. Thumb polydactyly as a part of the range of genetic expression for thenar hypopart of the range of genetic expresin Pediatr 1987;26:142-8.
plasia. Clin 